\title{
Valorization of Lactic Acid and Derivatives to Acrylic Acid Derivatives: Review of Mechanistic Studies
}

\author{
Elodie Blanco, Stéphane Loridant, and Catherine Pinel
}

\begin{abstract}
Lactic acid and acrylic acid are key platform molecules for a large range of applications, in particular polymers. While the production of lactic acid from biomass has been extensively described, much less literature concerns the synthesis of bioacrylic acid. Among the different potential routes, the dehydration of lactic acid or alkyl lactates to acrylic acid is still challenging, and this approach needs further optimization. In this chapter, we focus on mechanistic studies related to the dehydration of lactic acid to acrylic acid by considering potential relationships between acid-base properties and reaction selectivity.
\end{abstract}

Keywords Lactic acid and derivatives $\bullet$ Acrylic acid and derivatives $\bullet$ Dehydration

- Solid acid catalysts $\bullet$ Phosphates $\bullet$ Zeolites

\subsection{Introduction}

Despite significant price and demand and supply fluctuations in the oil market, the production of biodiesel from vegetable oil is well established and leads to the coproduction of large amounts of glycerol that must be valorized as much as possible. Together with traditional applications (food, tobacco or drug additive, alkyd resins, etc.), more recent applications have been pursued such as its use as an additive for animal feed or as a boiler fuel in the case of crude glycerol. Alternatively, considering the high number of functional groups of this small molecule, a large range of chemical or biochemical transformations have been studied to synthesize valueadded C3 chemicals. Many reports focused on the selective modification of glycerol either via fermentation or catalytic transformations [1]. The industrial scale

\footnotetext{
E. Blanco $\bullet$ S. Loridant $\bullet$ C. Pinel $(\bowtie)$

Institut de Recherches sur l'Environnement et la Catalyse de Lyon (IRCELYON), UMR 5256, CNRS - Université Lyon 1, 2 avenue Albert Einstein, F-69626 Villeurbanne Cedex, France

e-mail: stephane.loridant@ircelyon.univ-lyon1.fr; catherine.pinel@ircelyon.univ-lyon1.fr
} 
production of propylene glycol, epichlorohydrin (Solvay process), has already been reported. In general, it is important to optimize the synthesis of products with significant added value from superior polyols obtained from biomass [2]. In fact, polyols obtained from lignocellulosic biomass represent an abundant resource of nonedible raw material. Their upgrading to a large range of molecules has also been described [3]. Among all the potential platform molecules, acrylic acid and lactic acid are important chemicals, and they have significant price differentials to focus on.

In this review, we will describe the latest results concerning the catalytic dehydration of lactic acid to acrylic acid. We will concentrate on the comprehension of the mechanisms and on the nature of the catalytic sites involved in the process. First, the different routes for the synthesis of lactic acid and acrylic acid will be briefly summarized.

\subsection{Recent Developments in Lactic Acid and Acrylic Acid Synthesis}

\subsubsection{Lactic Acid Synthesis}

Production of lactic acid (LA) from biomass and its catalytic transformations to commodity chemicals has recently been reviewed [4-6]. Since its initial industrial production in 1881, the process has been substantially improved. Today, the main producers are Corbion Purac (NL), Galactic (BE), Archer Daniel Midland Company (ADM, US), and NatureWorks LLC (US) [7]. All these companies produce lactic acid via fermentation process of aqueous carbohydrate solutions under anaerobic conditions. This process presents some disadvantages such as limited space-time yields (fermentation takes 2-4 days), reactor control of fermentation (temperature and $\mathrm{pH}$ with addition of $\mathrm{Ca}(\mathrm{OH})_{2}$ ), and production of large amounts of waste (1 ton per 1 ton of lactic acid produced). Using Lactobacillus acidophilus or Streptococcus thermophilus as bacteria, optically active (L)-lactic acid is produced. Global production is higher than $300,000 \mathrm{t} / \mathrm{year}$ with an actual market price in the range $\$ 1300-1500 /$ t. Fermentation to (D)-lactic acid is also available but to a lesser extent [8] resulting in a more costly product. To reduce the price of (L)- or (D)-lactic acid, alternative cheaper starting materials, e.g., nonedible cereals contaminated with mycotoxins, have been evaluated. Alternatively, an efficient bioconversion of crude glycerol as obtained from the biodiesel process, to pure (D)-lactic acid (>99.9\% e.e.) by metabolically engineered Escherichia coli, has been reported [9].

Beyond this, several chemical syntheses of lactic acid are available. With this approach, typically racemic lactic acid is synthesized. However, an enantioselective reduction of pyruvic acid by either homogeneous or heterogeneous catalysts was also reported in literature. In the presence of chiral rhodium complexes, hydrogenation or hydrosilylation yielded up to $80 \%$ e.e. [10,11]. Lanthanide complexes were 

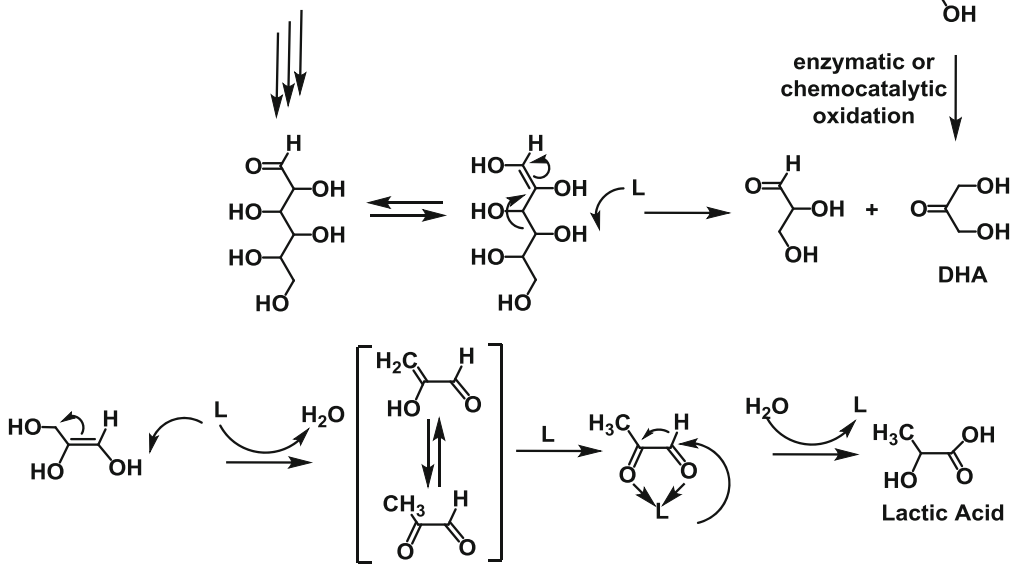

Fig. 3.1 Proposed reaction scheme for the formation of lactic acid from saccharides or glycerol in the presence of acid catalysts. $L=$ Lewis acid catalyst (Adapted from [14, 17, 24])

also reported to catalyze the reduction of sodium pyruvate with $\mathrm{NaBH}_{4}$, but the best e.e. reached only $50 \%$ [12]. Furthermore, enantioselective hydrogenation of pyruvic acid in the presence of platinum catalysts modified with cinchona alkaloid was carried out with $79 \%$ e.e. in alcoholic solvent [13]. This approach is of economic interest only to produce the more expensive (D)-lactic acid, the (L)-lactic acid being cheaper than pyruvic acid.

More recently, the production of lactic acid from poly-oxygenated derivatives has been extensively studied [5] following two main approaches. The first one starts from mono- or polysaccharides (C6 building blocks) for which retroaldol reaction is a key step [14]; the second one involves C3 building blocks (Fig. 3.1).

Homogeneous or heterogeneous acids catalyzed the conversion of mono- or even polysaccharides to a series of carboxylic acids [15]. In the presence of homogeneous lead (II) ions in water, up to $60 \%$ yield of LA was achieved after $4 \mathrm{~h}$ starting from microcrystalline cellulose [16]. The selectivity was significantly affected by the nature of the acid. It was suggested that Brønsted acid resulted mainly in the formation of levulinic acid and then 5-hydroxymethylfurfural, while Lewis acids favored the synthesis of lactic acid [17]. The following steps are proposed: glucose was isomerized to fructose that was subjected to a retroaldol reaction to give two $\mathrm{C} 3$ moieties. Then, dehydration followed by a 1,2-hydrogen shift yielded lactic acid (Fig. 3.1).

Retroaldol reactions may also be catalyzed under alkaline conditions, and the formation of lactic acid (up to $25 \%$ selectivity) was reported during the hydrogenolysis of polyols catalyzed by supported metallic catalysts in the presence of inorganic bases [18, 19]. When the reaction was carried out under inert atmosphere in the presence of $\mathrm{Ni}-\mathrm{Re} / \mathrm{C}$ catalyst and $\mathrm{Ba}(\mathrm{OH})_{2}$ as base, sorbitol was also partially 
transformed into lactic acid (17\% selectivity) [20]. The combination of $\mathrm{NaOH}$ and homogeneous nickel salts allowed the formation of lactic acid in $25 \%$ yield from glucose under hydrothermal conditions $\left(300^{\circ} \mathrm{C}, 1 \mathrm{~min}\right)$ [21].

Recently, it was shown that the nature of the atmosphere played also a significant role on the selectivity. In the presence of vanadyl cations $\left(\mathrm{VO}^{2+}\right)$, up to $56 \%$ yield of lactic acid were produced under inert atmosphere while formic acid was the main product under aerobic conditions [22]. It seems that even weak Lewis solid acids such as boehmite were able to catalyze the formation of lactic acid from monosaccharides [23].

An elegant approach was reported starting from glycerol, but in two steps. In that case, a selective enzymatic oxidation of glycerol was carried out first to produce dihydroxyacetone (DHA) which was subsequently isomerized to lactic acid in the presence of Lewis acid catalysts (Fig. 3.1). Gluconobacter oxydans was found to be efficient in the selective oxidation of glycerol to DHA [24], and recent developments allowed performing a transformation of crude glycerol [25]. Furthermore, some selective chemocatalytic aerobic oxidations in the presence of heterogeneous metallic catalysts have been also recently reported [26]. Gold-based catalysts exhibited high selectivity to DHA, even at high glycerol conversion, under neutral or basic conditions (Table 3.1) [27, 28]. Alternatively, some bimetallic catalysts (Pd$\mathrm{Ag}$ or Pt-Sb) were reported recently and yielded also high selectivity to DHA at up to $50 \%$ glycerol conversion $[29,30]$.

Finally, an efficient acid- or basic-catalyzed isomerization of DHA to LA in aqueous solution was reported. It was shown that solids containing Lewis acid sites were very selective for the transformation (up to $92 \%$ selectivity at $92 \%$ conversion), the main by-products being formic acid, acetic acid, and pyruvaldehyde [5, 24, 32, 33]. However, long-term stability and recyclability of these solids must be improved. A one-pot synthesis of LA from glycerol in the presence of Pt/Sn-MFI catalyst has also been described (Table 3.2) [34].

After the selective dehydrogenation step catalyzed by metallic platinum, DHA formed as an intermediate was isomerized to LA on Sn sites. At $100{ }^{\circ} \mathrm{C}$, under 6.2 bar $\mathrm{O}_{2}$, a $0.2 \mathrm{M}$ solution of glycerol in water was converted to $71 \% \mathrm{LA}$ after $24 \mathrm{~h}$ (initial TOF $=493 \mathrm{~h}^{-1}$ ). The combination of metallic and acidic sites was clearly established since glycerol was transformed to lactic acid (up to ca $50 \%$ at complete conversion) in the presence of $\mathrm{AuPd} / \mathrm{TiO}_{2}$ catalyst associated with homogeneous

Table 3.1 Selective oxidation of glycerol to dihydroxyacetone (DHA)

\begin{tabular}{|c|c|c|c|c|}
\hline Catalyst & Conditions & $\begin{array}{l}\text { Conv. } \\
\text { GLY }(\%)\end{array}$ & $\begin{array}{l}\text { Sel. } \\
\text { DHA } \\
(\%)\end{array}$ & Ref. \\
\hline $\mathrm{Au} / \mathrm{CuO}$ & $50^{\circ} \mathrm{C}, 20$ bar $\mathrm{O}_{2}, 4 \mathrm{~h}, \mathrm{GLY} / \mathrm{Au}=50$ & 98 & 82 & [27] \\
\hline $\mathrm{Au} / \mathrm{MWCNT}$ & $\begin{array}{l}60^{\circ} \mathrm{C}, 3 \text { bar } \mathrm{O}_{2}, 2 \mathrm{~h}, \mathrm{GLY} / \mathrm{Au}=555, \\
\mathrm{NaOH} / \mathrm{GLY}=2\end{array}$ & 93 & 60 & [28] \\
\hline $\mathrm{Pd}-\mathrm{Ag} / \mathrm{C}$ & $80^{\circ} \mathrm{C}, 3$ bar $\mathrm{O}_{2}, 24 \mathrm{~h}, \mathrm{GLY} / \mathrm{Pd}=115$ & 52 & 85 & {$[29,31]$} \\
\hline $\mathrm{Pt}-\mathrm{Sb} / \mathrm{MWCNT}$ & $60^{\circ} \mathrm{C}, 1$ bar $\mathrm{O}_{2,} \mathrm{GLY} / \mathrm{Pd}=500$ & 50 & 67 & {$[30]$} \\
\hline
\end{tabular}


Table 3.2 Selective oxidation of glycerol to lactic acid

\begin{tabular}{|c|c|c|c|c|}
\hline Catalyst & Conditions & $\begin{array}{l}\text { Conv. GLY } \\
(\%)\end{array}$ & $\begin{array}{l}\text { Sel. LA } \\
(\%)\end{array}$ & Ref. \\
\hline $\mathrm{Pt} / \mathrm{Sn}-\mathrm{MFI}$ & $100^{\circ} \mathrm{C}, 6.2$ bar $\mathrm{O}_{2}, 24 \mathrm{~h}$, & 90 & 81 & {$[34]$} \\
\hline AuPt/USY-600 & $180^{\circ} \mathrm{C}, 3$ bar $\mathrm{O}_{2}, 2 \mathrm{~h}$ & 80 & 60 & [35] \\
\hline $\mathrm{AuPt} / \mathrm{TiO}_{2}$ & $\begin{array}{l}90^{\circ} \mathrm{C}, 1 \text { bar } \mathrm{O}_{2}, 0.5 \mathrm{~h}, \mathrm{NaOH} / \\
\mathrm{GLY}=4\end{array}$ & 99 & 86 & [36] \\
\hline $\mathrm{Au} / \mathrm{CeO}_{2}$ & $90^{\circ} \mathrm{C}, 1$ bar air, $2 \mathrm{~h}, \mathrm{NaOH} / \mathrm{GLY}=4$ & 98 & 83 & {$[37]$} \\
\hline $\mathrm{AuPt} / \mathrm{CeO}_{2}$ & $\begin{array}{l}100^{\circ} \mathrm{C}, 5 \text { bar } \mathrm{O}_{2}, 0.5 \mathrm{~h}, \mathrm{NaOH} / \\
\mathrm{GLY}=4\end{array}$ & 99 & 80 & {$[38]$} \\
\hline $\mathrm{PtNiOx} / \mathrm{TiO}_{2}$ & $90^{\circ} \mathrm{C}, 1$ bar $\mathrm{O}_{2}, 2 \mathrm{~h}, \mathrm{NaOH} / \mathrm{GLY}=4$ & 99 & 63 & [39] \\
\hline $\mathrm{Pt} / \mathrm{C}$ & $\begin{array}{l}200^{\circ} \mathrm{C}, 40 \text { bar } \mathrm{H}_{2}, 5 \mathrm{~h}, \mathrm{NaOH} / \\
\mathrm{GLY}=10\end{array}$ & 92 & 47 & [43] \\
\hline $\mathrm{Ir} / \mathrm{C}$ & $\begin{array}{l}200^{\circ} \mathrm{C}, 30 \text { bar } \mathrm{He}, 12 \mathrm{~h}, \mathrm{NaOH} / \\
\mathrm{GLY}=4\end{array}$ & 96 & 51 & {$[42]$} \\
\hline $\mathrm{Pt} / \mathrm{ZrO}_{2}$ & $\begin{array}{l}180^{\circ} \mathrm{C}, 30 \text { bar } \mathrm{He}, 24 \mathrm{~h}, \mathrm{NaOH} / \\
\mathrm{GLY}=1.8\end{array}$ & 95 & 84 & {$[40]$} \\
\hline$\left[(\mathrm{CO})_{2}(\mathrm{NHC})_{2} \mathrm{Ir}\right] \mathrm{BF}_{4}$ & $115^{\circ} \mathrm{C}, \mathrm{N} 2,24 \mathrm{~h}, \mathrm{KOH} / \mathrm{GLY}=1.1$ & 90 & 97 & {$[41]$} \\
\hline
\end{tabular}

$\mathrm{AlCl}_{3}$, while in the presence of $\mathrm{AuPd} / \mathrm{TiO}_{2}$, only the formation of DHA was significantly higher [25]. Similarly, gold-platinum catalysts supported on acidic zeolites exhibited identical behavior, and $60 \%$ LA selectivity was achieved at $80 \%$ glycerol conversion [35]. In the presence of base, $\mathrm{AuPt} / \mathrm{TiO}_{2}, \mathrm{Au} / \mathrm{CeO}_{2}, \mathrm{AuPt} / \mathrm{CeO}_{2}$, and $\mathrm{PtNiOx} / \mathrm{TiO}_{2}$ were efficient for the direct transformation of glycerol to LA under air or oxygen atmosphere [36-39]. Also, in the presence of noble metallic catalyst (Ir, $\mathrm{Rh}, \mathrm{Ru}$, or Pt based), and under inert or reductive atmosphere, the formation of lactic acid in alkaline conditions has been described [25, 40, 42, 43]. In the presence of $\mathrm{Pt} / \mathrm{ZrO}_{2}$, up to $84 \%$ selectivity was achieved at $95 \%$ conversion. Regardless of the nature of the atmosphere employed, it was expected that the first step is a dehydrogenation yielding the aldehyde or ketone [44]. Successive dehydration and isomerization steps then produce lactic acid. Some homogeneous iridium complexes were efficient to promote the selective conversion of glycerol to lactic acid under mild conditions, and the system does not seem to be air sensitive [41].

In the literature, a hydrothermal decomposition of glycerol in basic conditions was also documented, and up to $90 \%$ yield of lactic acid were achieved [45]. The use of inexpensive solid $\mathrm{CaO}$ was described to give $41 \%$ of LA starting from pure or crude glycerol [46]. However, the water content must be below $10 \%$ to avoid formation of less efficient $\mathrm{Ca}(\mathrm{OH})_{2}$.

Lactic acid is registered as an antibacterial agent. It is also used as a preservative or $\mathrm{pH}$-adjusting agent in food and beverages. Furthermore, it is mainly used in polymer industry to produce PLA (polylactic acid) which is a compostable and biodegradable thermoplastic polymer with broad applications in food packaging (film or rigid containers) [47]. Under composting conditions, PLA bottles were completely degraded after $30 \mathrm{~h}$ at $65^{\circ} \mathrm{C}$. Furthermore, for medical applications such as surgical 


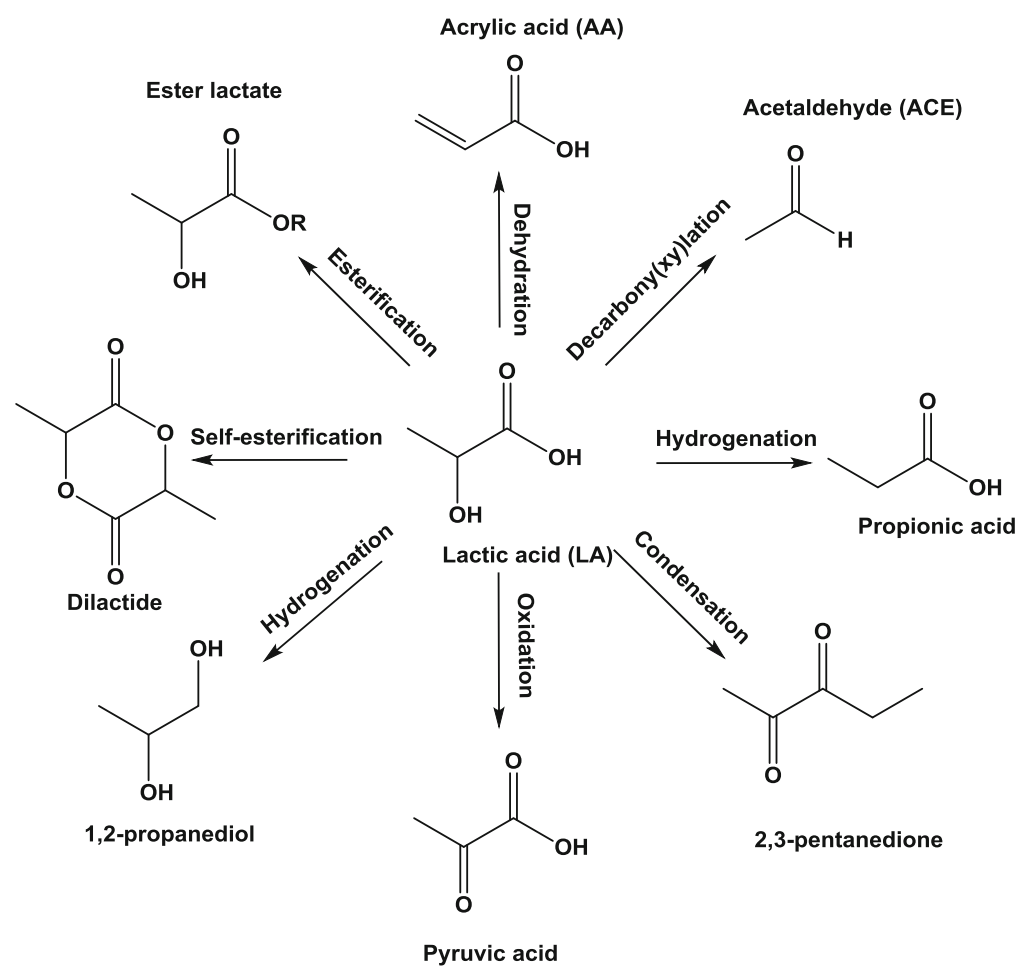

Fig. 3.2 Commodity chemicals obtained by LA conversion (Adapted from Fan et al. [4])

sutures or drug delivery materials, it has been shown that PLA is initially depolymerized by partial hydrolysis followed by metabolization of the resulting oligomers in cells. Racemic lactate esters (ethyl and butyl derivatives) find applications as biodegradable and safe solvents [48] used in pharmaceutical, cosmetic, coating, food, and fragrance production. Because LA possesses two reactive functions $(\mathrm{OH}$ and $\mathrm{COOH}$ ), it has also the potential to become a central feedstock for the chemical industry as it can be converted into numerous products as illustrated in Fig. 3.2. Most of the transformation takes place either starting from acid or ester derivatives of lactic acid.

Among these products, acetaldehyde (ACE) is an intermediate for preparation of several $\alpha, \beta$-unsaturated aldehydes, acetic acid or anhydride, and ethyl acetate [49]. It is currently produced by the Wacker process [50] from ethylene which is a cheap intermediate. Acetaldehyde can also be easily obtained by decarbonylation and decarboxylation (Fig. 3.3) of LA. However, the interest of such reactions is rather limited because of the low cost of ACE together with the by-production of $\mathrm{CO}$ or $\mathrm{CO}_{2}$, and only a few papers are reported in the literature [49, 51]. Nevertheless, aceldehyde is often considered together with acrylic acid (AA) formation since it corresponds to the main by-product. 
Fig. 3.3 Different pathways of formation of acetaldehyde (ACE) from lactic acid
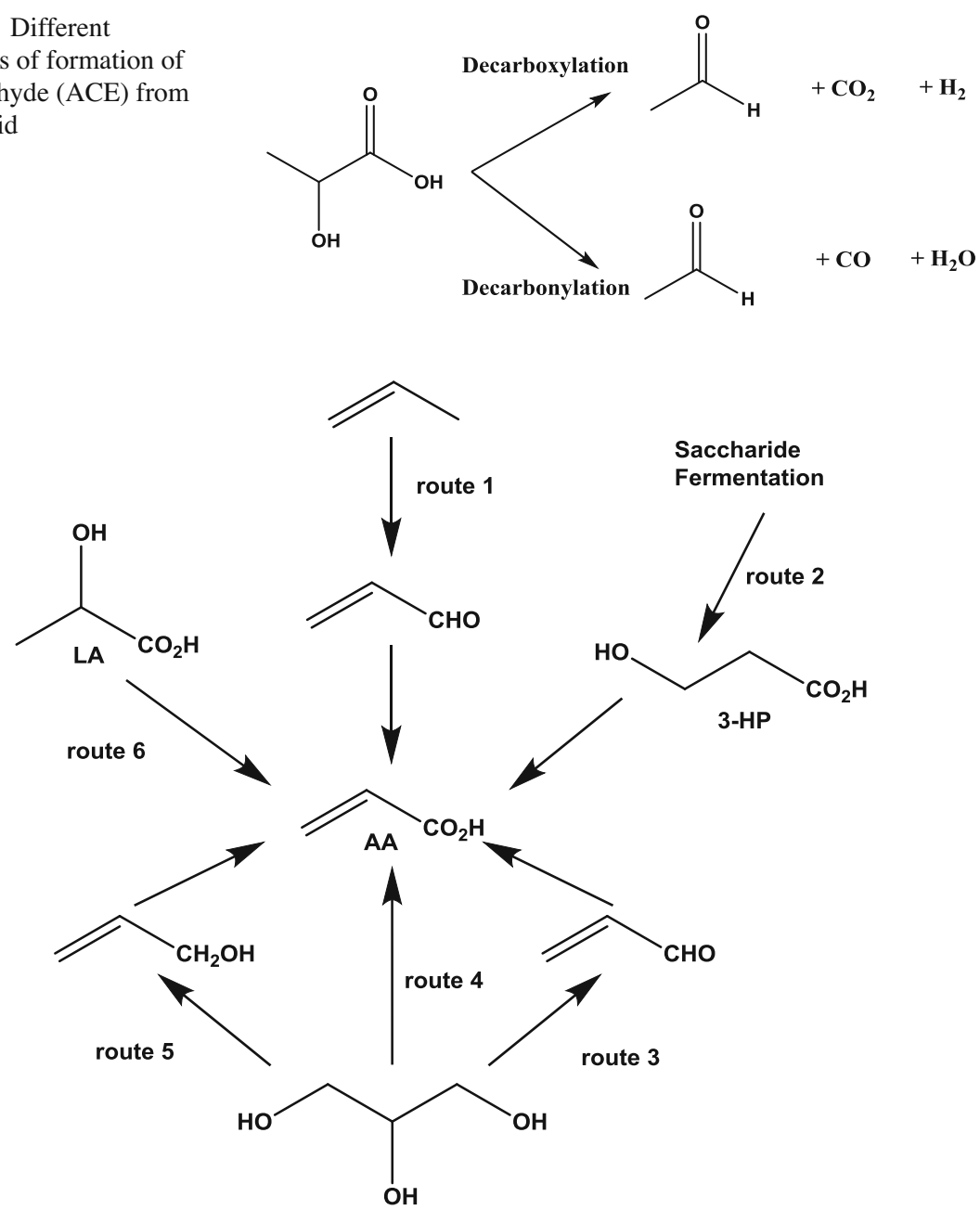

Fig. 3.4 Different routes to synthesize acrylic acid

\subsubsection{Acrylic Acid Synthesis}

Acrylic acid is the more valuable product because it has a large market (8.5-11.5 billion $€$ /year). Furthermore, its production of $\sim 4.2 \mathrm{Mt}$ in 2011 has grown $4 \%$ /year between 2006 and 2011 and was predicted to increase about $5 \% / y e a r$ between 2012 and 2017 [52]. Acrylic acid is a primary intermediate for paints, polymers, and acrylic esters. Major markets for the esters include surface coatings, textiles, adhesives, and plastics [53-55]. Polyacrylic acid or copolymers find applications in superabsorbents, detergents, dispersants, flocculants, and thickeners. Superabsorbent polymers are used mainly in disposable nappies.

Acrylic acid is currently produced by catalytic oxidation of propylene using a two-step process (Fig. 3.4, route 1). However, it is widely affected by the propylene 
price as it represents only $2 \%$ of its global consumption [3]. At the present time, the propylene demand is increasing faster than its supply leading to the so-called propylene gap and increases in its price [56]. An alternative route to produce AA is therefore required especially in the context of the development of environmentfriendly catalytic processes. Therefore, several syntheses from biomass are under development. AA may be produced in two steps via the formation of 3-hydroxypropionic acid (3-HP) (route 2). In the first step, genetically modified microorganisms were developed to produce relatively high concentration of 3-HP ( $>10 \mathrm{~g} / \mathrm{L}$ ) from saccharides under specific culture conditions [57] or from glycerol $[58,59]$. The resulting fermentation broth was concentrated $(>250 \mathrm{~g} / \mathrm{L})$ and $3-\mathrm{HP}$ was purified. The 3-HP solution was vaporized and dehydrated to acrylic acid at 300 ${ }^{\circ} \mathrm{C}$ in the presence of a slightly acid or neutral support [60]. In September 2014, BASF, Cargill, and Novozyms announced they have established commercial scale production of 3-HP to acrylic, while fermentation optimization toward commercial scale requirements is still under development [28]. Some fermentation processes to transform glycerol to 3-HP were also reported [61].

Among different bioresources, glycerol is probably the most promising to synthesize acrylic acid since the growing biodiesel production favors its availability in large volumes as the by-product during transesterification reaction of vegetable oil. Firstly, the glycerol to AA transformation can be achieved via acrolein in two steps (route 3), the second step (oxidation of acrolein) being already industrialized. However, even though efficient catalysts were developed for glycerol dehydration to acrolein with yields reaching $80 \%$, [62-64] they all suffered from lack of long-term stability on stream requiring regenerative processes, which would make them noncompetitive at the present time. For both economical and chemical process reasons, an interesting alternative is the single-step oxidehydration of glycerol by means of a bifunctional catalyst (route 4). Among different catalysts, hydrothermally prepared $\mathrm{W}-\mathrm{V}-\mathrm{Nb}$ mixed oxides with hexagonal tungsten bronze (HTB) structure stand out with the best AA yield ( $\sim 50 \%)$ in the presence of a well-defined glycerol-tooxygen inlet $[65,66]$, but such yield still remains insufficient. Acrylic acid may also be obtained from glycerol via allylic alcohol (route 5). The selective transformation of glycerol to allylic alcohol was followed by selective oxidation in the presence of a cerine (allanite-Ce)-supported gold catalyst under basic conditions [67]. Homogeneous catalysts such as methyltrioxorhenium were reported to be active in the deoxygenation of glycerol to allylic alcohols [68]. To our knowledge, this route has however only been studied at laboratory scale.

Finally, acrylic acid could be obtained from lactic acid (route 6). Direct LA dehydration to acrylic acid is also attractive since it corresponds to one-step process, and lactic acid can be produced cheaply from a large range of starting material (vide supra). However, this route is currently limited by the low LA production (only 330 $\mathrm{kt}$ in 2015 [69] versus 4.5 Mt for acrylic acid). 


\subsection{Lactic Acid Dehydration to Acrylic Acid}

LA dehydration has been studied in near-critical water [70-72] and in the presence of enzymatic [73], homogeneous [74], and heterogeneous catalysis [4, 5]. In this part, a summary of the best performances obtained by heterogeneous catalysts and key parameters favoring AA formation will be presented. Then, mechanistic studies on LA dehydration will be discussed with regard to its competing decarbony(xy) lation.

\subsubsection{Best Performances}

Tables 3.3 and 3.4 gather the best yields in AA claimed in the patents and reported in the open literature, respectively, and the corresponding catalysts used focusing on the use of heterogeneous catalysts.

Modified zeolites [79, 80, 84-90], sulfates/nitrates [81, 91, 92], and phosphates $[82,83,93-103]$ were specifically investigated. The comparison of the catalytic performances is rather difficult since the optimal reaction conditions are different for each report. Regardless, the main family of efficient catalysts corresponded to phosphates, and the best yields were obtained using alkaline earth metal phosphates (up to $85 \%$ AA yield). Furthermore, such catalysts were stable for at least $24 \mathrm{~h}$ on stream [82, 99, 103], while modified zeolites showed poor stability [79, 80, 90].

Table 3.3 Best performances as claimed in patents for LA dehydration and corresponding catalysts

\begin{tabular}{l|l|l|l|l|l}
\hline Catalyst & $\begin{array}{l}\text { LA conc. } \\
(\% \mathrm{wt})\end{array}$ & $\begin{array}{l}\mathrm{T} \\
\left({ }^{\circ} \mathrm{C}\right)\end{array}$ & $\begin{array}{l}\text { LA conv. } \\
(\%)\end{array}$ & $\begin{array}{l}\text { AA yield } \\
(\text { sel. })(\%)\end{array}$ & Ref. \\
\hline $\mathrm{AlPO}_{4}$ & a & 340 & 100 & $61(61)$ & {$[75]$} \\
\hline $\mathrm{NaH}_{2} \mathrm{PO}_{4}+\mathrm{NaHCO}_{3} / \mathrm{SiO}_{2}$ & 20 & 350 & 89 & $58(65)$ & {$[76]$} \\
\hline $\begin{array}{l}\mathrm{Calcium} \text { phosphate } \\
(\mathrm{Ca} / \mathrm{P}=1.5-1.9)\end{array}$ & 50 & 375 & 100 & $70(70)$ & {$[77]$} \\
\hline Barium phosphate & 20 & 350 & 91 & $85(93)$ & {$[78]$} \\
\hline
\end{tabular}

${ }^{a}$ Ammonium lactate fed as reactant

Table 3.4 Best performances reported in open literature for LA dehydration and corresponding catalysts

\begin{tabular}{l|l|l|l|l|l}
\hline & $\begin{array}{l}\text { LA conc. } \\
(\% \text { wt })\end{array}$ & $\begin{array}{l}\text { T } \\
\left({ }^{\circ} \mathrm{C}\right)\end{array}$ & $\begin{array}{l}\text { LA conv. } \\
(\%)\end{array}$ & $\begin{array}{l}\text { AA yield (sel.) } \\
(\%)\end{array}$ & Ref. \\
\hline $\mathrm{Na}_{2} \mathrm{HPO}_{4} / \mathrm{NaY}$ & 34 & 340 & 93 & $73(79)$ & {$[79]$} \\
\hline $\mathrm{K}_{0.94} \mathrm{Na}_{0.06} \beta$ & 10 & 360 & 95 & $61(64)$ & {$[80]$} \\
\hline $\mathrm{BaSO}_{4}$ & 20 & 400 & 100 & $74(74)$ & {$[81]$} \\
\hline $\mathrm{Ca}_{5}\left(\mathrm{PO}_{4}\right)_{3} \mathrm{OH}(\mathrm{Ca} / \mathrm{P}=1.62)$ & 36 & 360 & 83 & $74(89)$ & {$[82]$} \\
\hline $\mathrm{Ca}_{2} \mathrm{P}_{2} \mathrm{O}_{7}(\mathrm{Ca} / \mathrm{P}=0.72)$ & 25 & 375 & 100 & $78(78)$ & {$[83]$} \\
\hline
\end{tabular}


However, significant various AA selectivity values (from 50 to $80 \%$ ) were reported even for similar reaction conditions or catalysts studied [82, 83, 93, 98, 99, 103]. Such differences could arise from the analytical method used for LA quantification during the catalytic tests [82]. Indeed, it was suggested that the use of GC analysis may not be reliable for LA conversion higher than $70 \%$ or when LA concentration in the condensate is lower than $15 \%$. As an example, the authors showed that for one condensate, GC analysis gave a complete LA conversion, while using ionic chromatography (IC), a value of $80 \%$ was obtained. Partial dissociation of LA into anionic lactate would occur during GC analysis leading to erroneous values [82]. Differences in AA selectivity could also be due to the vaporization device employed [104]. Indeed, Näfe et al. [104] pointed out that in several cases, liquid feed was pumped and vaporized in a zone just above the catalytic bed leading to carbonaceous deposit formation on the top of the catalytic bed which amounted to incomplete vaporization and partial polymerization of LA. They compared LA conversion and AA selectivity obtained in their setup, for which the feed was vaporized just at the entrance of the reactor, with results published by Sun et al. [84] over NaY zeolites in an integrated reactor-evaporator setup. Similar AA yields were reached but with lower LA conversion (higher AA selectivity) in the former case. Therefore, an integrated reactor-evaporator setup can alter catalytic measurements because of formation of carbon deposit due to incomplete vaporization and LA polymerization.

\subsubsection{AA Versus ACE Selectivity: Key Parameters}

In this section, the influence of different parameters on AA and ACE selectivity values is detailed to identify the key ones. First, we will consider the influence of the reaction conditions on the selectivity AA/ACE; second, we will detail the role of the catalyst properties.

\subsubsection{Reaction Conditions}

Optimization of reaction parameters was first reported by Miller et al. in the presence of supported sodium nitrate catalysts [105]. Their study showed that AA formation is favored by a low contact time and a temperature above $370{ }^{\circ} \mathrm{C}$, and the same conclusions were drawn for phosphates by Ghantani et al. [93]. Furthermore, Miller et al. have studied the optimal temperature for AA formation in the presence of a series of alkali metal salts [106], and it was shown that it depended on the nature of the salt which was corroborated later by others studies [90, 107].

Concerning the ACE formation, blank testing revealed that a thermal pathway existed since ACE selectivity increased from 23 to $40 \%$ rising the temperature from 350 to $400{ }^{\circ} \mathrm{C}$ [72]. In the presence of catalyst, an optimal temperature of $380{ }^{\circ} \mathrm{C}$ 
was determined, and acetic acid was obtained at higher temperature $\left(420^{\circ} \mathrm{C}\right)$ [51]. Hence, the temperature ranges to obtain AA and ACE were similar, indicating that ACE formation cannot be avoided changing this parameter without affecting selectivity to AA.

The effect of contact time on the product selectivity was also investigated. Constant values of AA and ACE selectivities were measured varying the contact time between 0.5 and $4.1 \mathrm{~s}$ over alkaline earth metal phosphates suggesting that parallel reactions occurred [103]. Nevertheless, a small optimum for AA selectivity was observed in several cases: for example, for an LA conversion range of 50-97 \%, the AA selectivity varied from 59 to $74 \%$ with a maximum at $84 \%$ LA conversion $[82,83,105]$.

Finally, the effect of LA concentration on conversion and product selectivity was also studied. As expected, increasing LA solution concentration leads to a decrease in the conversion and increase in AA selectivity [80, 83, 90, 91], though increasing LA concentration also leads to a faster deactivation in the case of zeolites [80] probably because bimolecular reactions were favored at high LA partial pressure increasing the carbonaceous deposits.

\subsubsection{Catalyst Properties}

Wang et al. studied zeolites modified with rare earths and found that addition of $\mathrm{La}^{3+}$ and $\mathrm{Ce}^{4+}$ improved AA selectivity [86]. The Rietveld refinement of diffractograms revealed that $\mathrm{Na}^{+}$cations were located in the $\mathrm{S} 4$ supercage, while $\mathrm{La}^{3+}$ and $\mathrm{Ce}^{4+}$ were in the S2 sodalite cage (Fig. 3.5). LA dehydration would occur in the sodalite cage suggesting that the introduction of rare earth cations generated a charge effect as the origin of a better efficiency.

Zeolites modified by potassium halogen salts $(\mathrm{KX})$ were investigated by Sun et al. [84, 85]. Since Lewis acidity decreases with increasing cation size [108], sub-

Fig. 3.5 Five sites available to nonframework ions in zeolites (Reprinted with permission from Ref. [86]. Copyright 2008 Elsevier)

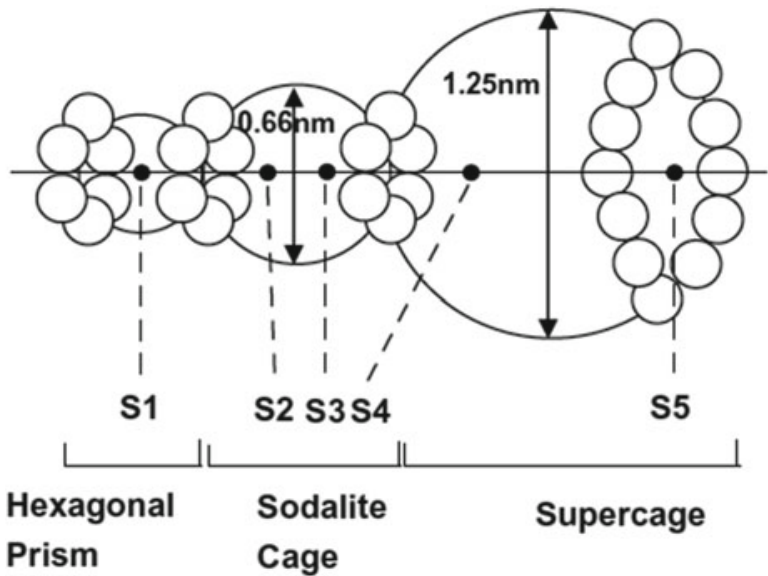


stitution of $\mathrm{Na}^{+}$by $\mathrm{K}^{+}$cations decreased acidity and the AA yield was improved. Furthermore, $\mathrm{X}^{-}$anions increase the basicity of the adjacent $\mathrm{O}^{2-}$ anions which was proposed to prevent ACE formation.

This was confirmed with different alkali metal salts [106, 107, 109]. The negative role of high acidity was also shown for nonmodified zeolites. Indeed, a higher AA selectivity was reached by decreasing the strength and density of acid sites [84-86, 89, 90]. More recently, a clear correlation between AA selectivity achieved in the presence of alkaline earth metal phosphates and the acid-base balance was clearly established: the AA selectivity was $50 \%$ and $25 \%$ for an acid-base balance of 1.3 and 2, respectively [103]. Another correlation was reported over different hydroxyapatites: a volcano plot of the AA production rate versus the acid-base balance showed an optimal balance of 4 , and a cooperative acid-base catalysis was suggested [82]. This conclusion was corroborated in parallel by Matsuura et al. who observed on calcium hydroxyapatites that AA selectivity could be correlated to the number of moderately basic sites and concluded that since purely basic catalysts such as $\mathrm{MgO}$ were not selective for this reaction, an adequate balance between moderately acidic and basic sites is necessary suggesting that acid-base pairs are active in the mechanism $[98,99]$. Interestingly, the acid-base properties of hydroxyapatites can be modulated by the calcination temperature and the $\mathrm{M} / \mathrm{P}$ ratio [82]. The difference of optimal balance reported in the studies of Blanco et al. [103] and Yan et al. [82] can be attributed to the easy carbonation of hydroxyapatites during TPD- $\mathrm{CO}_{2}$ measurements which would lead to an underestimation of the density of basic sites [110].

Regarding acetaldehyde, a maximal ACE yield ( $84 \%$ ) was reached under supercritical conditions $\left(385^{\circ} \mathrm{C}, 5000 \mathrm{psi}\right)$ after addition of $100 \mathrm{mM}$ of sulfuric acid, while a much smaller yield ( $23 \%$ ) was obtained when $81 \mathrm{mM}$ solution of sodium hydroxide was used [72]. This clearly indicated that decarbony(xy)lation is favored by acidic sites. Keeping this in mind, the catalytic properties of sulfate-based catalysts and heteropolyacids (HPAs) were compared. The latter ones were more active but less stable than the sulfates. The improved stability was attributed to a higher proportion of moderate acidic sites [51]. Similarly, acidity was shown to be a key parameter using HPAs supported on several silica supports [49]: the higher the density of acid sites, the higher the ACE molar selectivity with a maximum of $98 \%$ at $85 \%$ conversion for $20 \mathrm{wt} \% \mathrm{H}_{4} \mathrm{SiW}_{12} \mathrm{O}_{40} / \mathrm{SBA}-15$ versus $88 \%$ at $86 \%$ conversion in the case of $\mathrm{H}_{4} \mathrm{PW}_{12} \mathrm{O}_{40} / \mathrm{SBA}-15$. However, acetaldehyde could also be formed by decarboxylation over basic catalytic sites [107].

On the whole, AA formation seems to be favored by acid-base pairs in which acidic and basic sites are weak or/and moderated while ACE formation needs stronger acidity or basicity. Therefore, the role of the active sites has to be investigated in order to better understand the reaction mechanisms and prevent LA decarbony(xy) lation. 
Fig. 3.6 Bidentate adsorption modes of LA at the surface of monoclinic $\mathrm{ZrO}_{2}$ (Reprinted with permission from Ref. [111]. Copyright 2013 Elsevier)
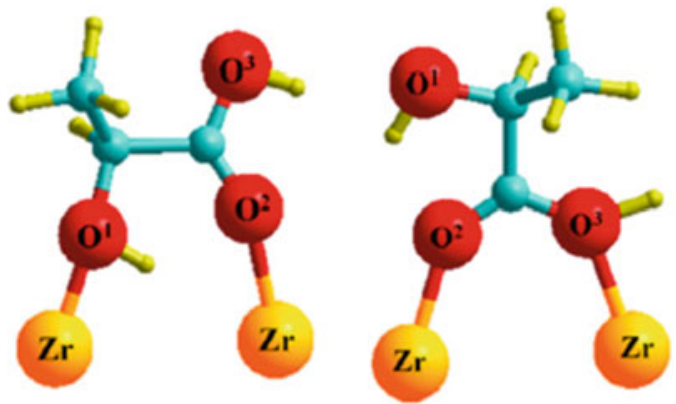

\subsubsection{Mechanistic Studies}

Several theoretical mechanistic studies based on DFT calculations were carried out addressing different types of oxides. Initially, Paul et al. [111] investigated LA adsorption modes on $\mathrm{ZrO}_{2}$ surfaces. LA is preferentially stabilized in a bidentate bridging mode with $\mathrm{O}-\mathrm{H}$ bond dissociation whatever the studied surface (Fig. 3.6), and this adsorption mode was also confirmed over MgO catalyst [112]. Subsequently, some dehydration mechanisms were investigated [111]. The results showed that an E1cb mechanism was energetically more favorable than E1. However, in this work, an E2-concerted mechanism has not been considered.

LA dehydration and decarbony(xy)lation through stepwise or concerted mechanisms were both considered over sodium triphosphate [102]. As shown in Fig. 3.7, a concerted mechanism was more favorable for LA dehydration with an activation barrier of $259 \mathrm{~kJ} / \mathrm{mol}$. This indicates that acid-base pairs might be involved with interactions of $\mathrm{P}-\mathrm{O}^{-}$and $\mathrm{P}-\mathrm{OH}$ species with the protons of the methyl and the $\mathrm{OH}$ groups of LA, respectively. In the case of LA decarbonylation, calculation of the activation barrier showed that a stepwise mechanism is preferred $(180 \mathrm{~kJ} / \mathrm{mol})$. This involves the formation of a phosphate ester, which then decomposes to give acetaldehyde and carbon monoxide. Hence, decarbonylation of LA should be the predominant reaction over sodium triphosphates, but unfortunately these results were not corroborated by experimental data.

Jackson and Miller groups attempted to experimentally identify the active phase of the catalyst. The presence of lactates adsorbed on cations at the surface of catalysts after reaction was evidenced by IR spectroscopy for different salts [94, 95, 105-107, 113]. It was concluded that their formation is a key parameter to obtain selectively AA. The same conclusion was drawn for zeolites [90] and phosphates $[82,83,93,103]$.

Based on these results, Gunter et al. [94, 95, 105-107, 113] proposed two adsorption modes of LA (Fig. 3.8). The first one corresponded to a phosphate ester and was suggested to be the activation mode to form the undesired ACE. The second one was a cyclic phosphate that can be stabilized by resonance effects, analog to the one proposed and generally accepted for the conversion of methyl- $\alpha$-acetoxy propionate into methyl acrylate by acetic acid elimination [114, 115]. Additionally, 


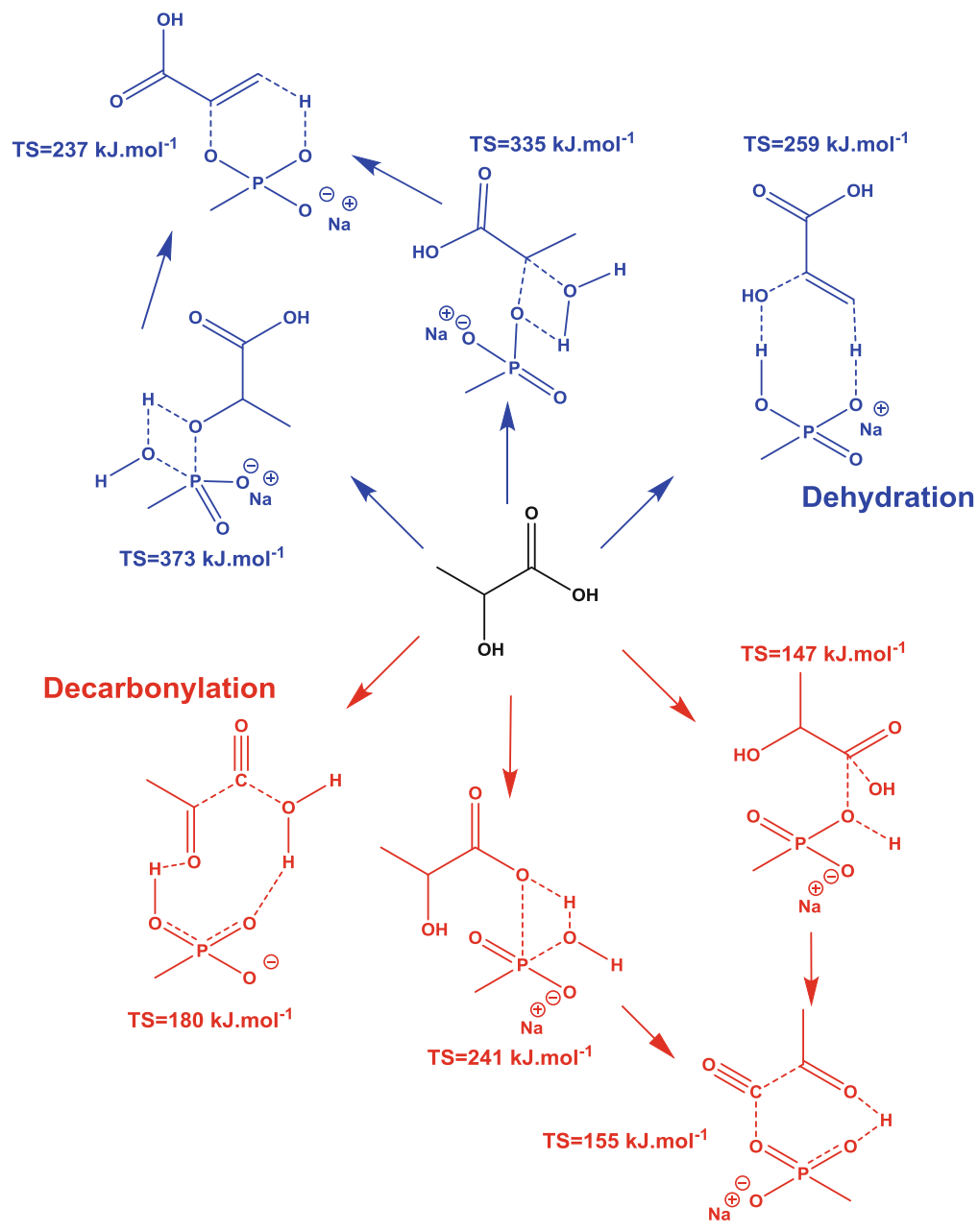

Fig. 3.7 Calculated transition state energy diagrams of LA dehydration and decarbonylation over sodium tripolyphosphate (Adapted from Zhang et al. [102])

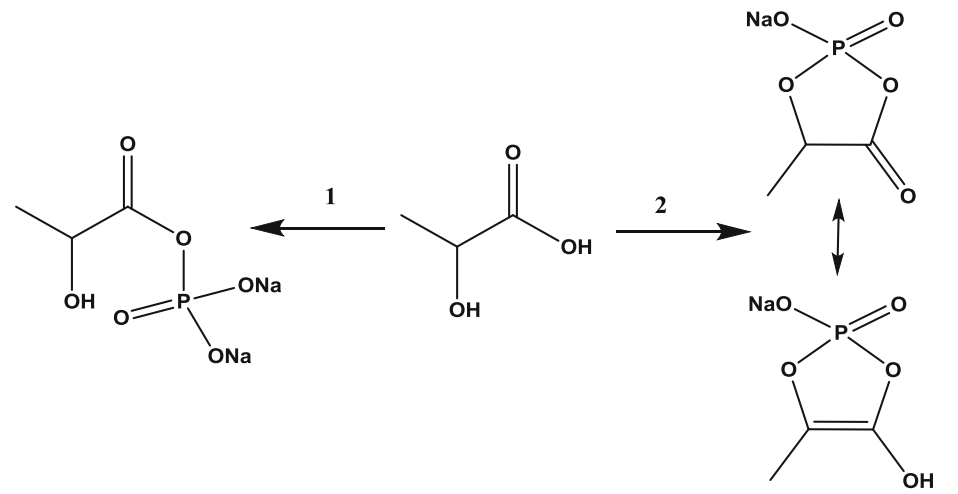

Fig. 3.8 Activation modes of $\mathrm{LA}$ over $\mathrm{Na}_{3} \mathrm{PO}_{4}$ proposed by Gunter et al. [94, 95, 105-107, 113] 


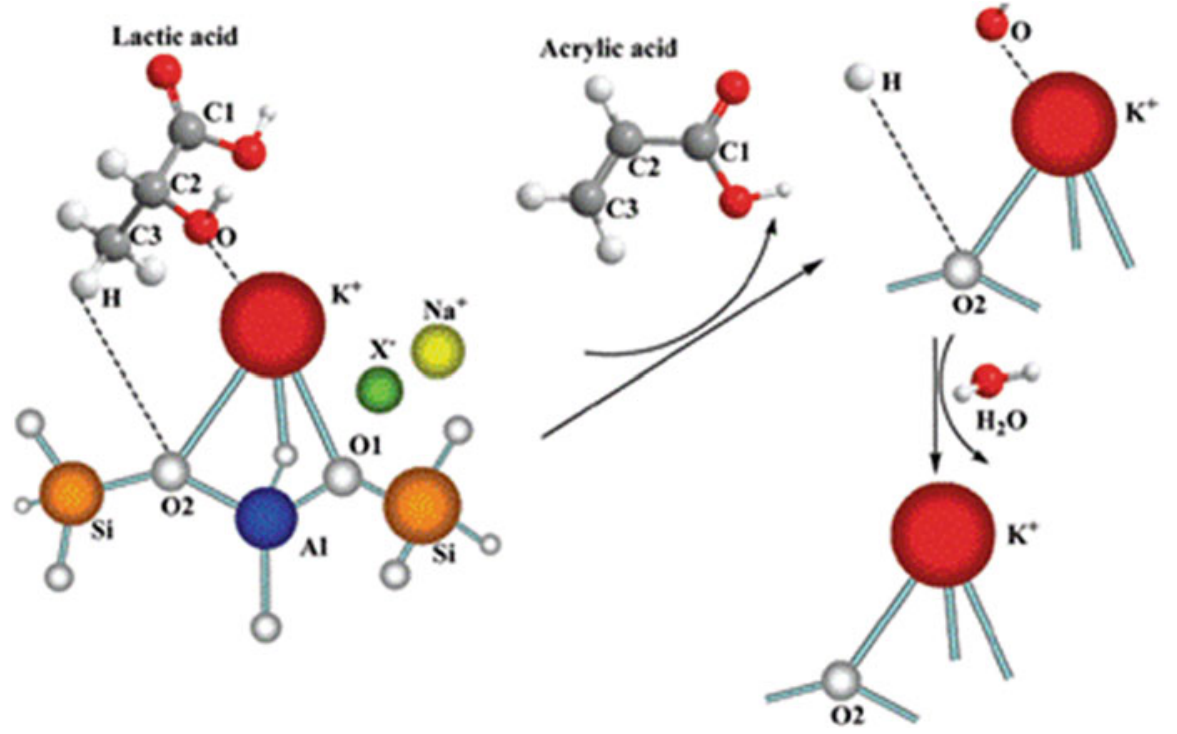

Fig. 3.9 Scheme of LA dehydration to AA over KX-modified NaY zeolites proposed by Sun et al (Reprinted with permission from Ref. [85]. Copyright 2010 American Chemical Society)

they concluded that the formation of this phosphate was favorable for LA dehydration by estimating the activation energy of the transition state.

In the following, it was proposed that LA adsorption over alkali-modified zeolites is bidentate [85].

This corresponds to complementary interactions between basic oxygen atom of the catalyst and acidic proton on the $\mathrm{C} 3$ atom and between cation (Lewis acid) and the $\mathrm{OH}$ group of the $\mathrm{C} 2$ atom (Fig. 3.9), but the carboxylate group is not stabilized through lactate formation. However, this mode of adsorption suggests that an acidbase pair is involved in LA dehydration through an E2 mechanism. LA dehydration was shown to be favored by a low electrostatic potential for alkali-modified $\beta$-zeolites [80]. In the reaction mechanism proposed from this observation (Fig. 3.10), activation of LA occurs by the interaction of a proton from the carboxylic function with one basic oxygen giving to the formation of alkali lactate (step 1). This lactate is believed to stabilize the carboxyl function inhibiting decarbony(xy) lation conducting to acetaldehyde formation. Then, a bidentate LA adsorption involving an acid-base pair (step 2) was proposed in agreement with Sun et al. [15]. Finally, elimination of one water molecule through an E2 mechanism results in formation of an alkali acrylate which exchanged its cation with a proton of the catalyst in order to release AA (step 3).

In the case of hydroxyapatites, the dehydration rate was correlated to the surface calcium deficiency and hence, to the surface concentration of hydrogenophosphate groups [93]. Assuming calcium lactate formation, AA is proposed to be formed through a cyclic phosphate (Fig. 3.11), while ACE is obtained after adsorption mode involving the $\mathrm{OH}$ group and consecutive formation of phosphate ester. 


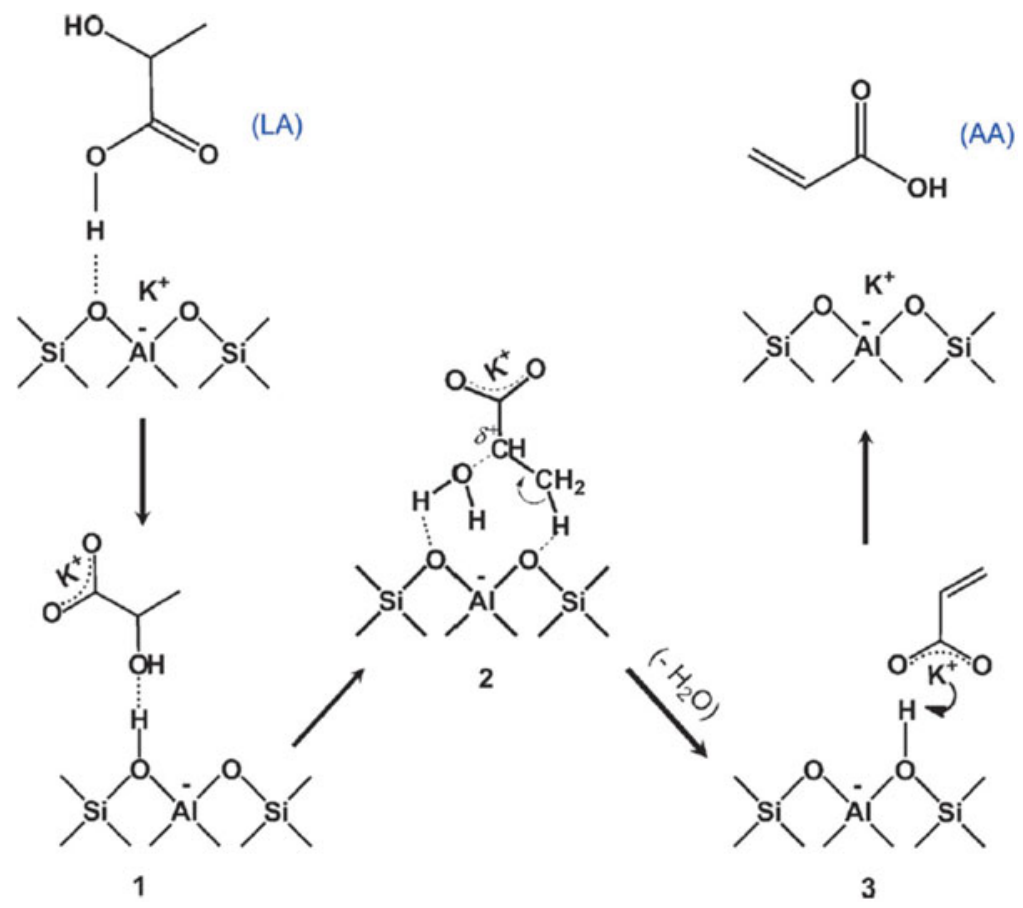

Fig. 3.10 Dehydration mechanism over $\mathrm{K}_{\mathrm{m}} \mathrm{Na}_{1-\mathrm{m}} \beta$ catalysts proposed by Yan et al. (Reprinted with permission from Ref. [80]. Copyright 2014 Wiley)

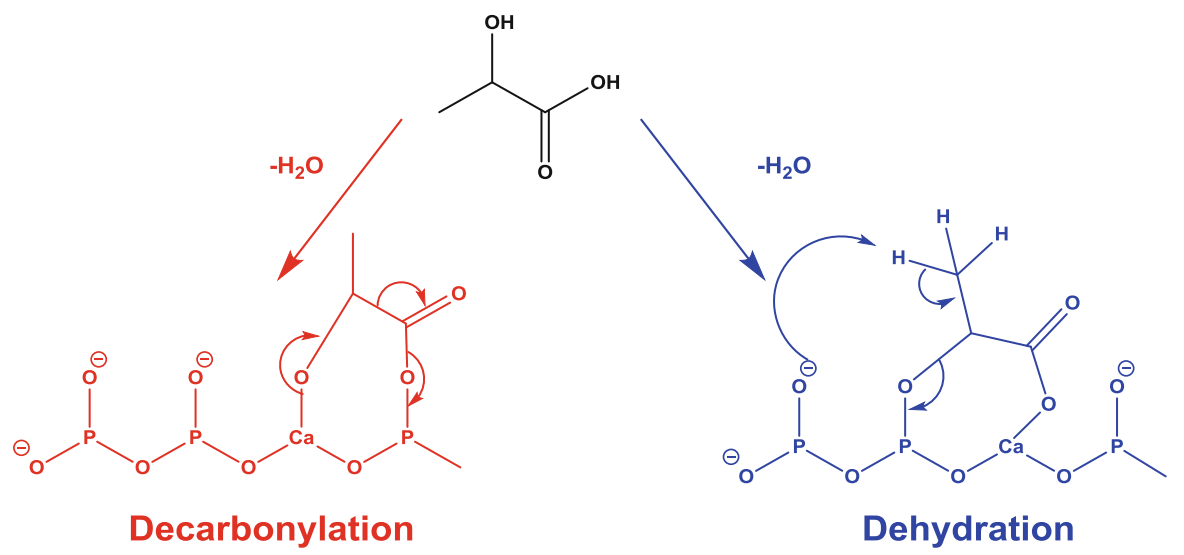

Fig. 3.11 Dehydration and decarbonylation mechanisms using Ca-deficient hydroxyapatites (Adapted from by Gantani et al. [93]) 


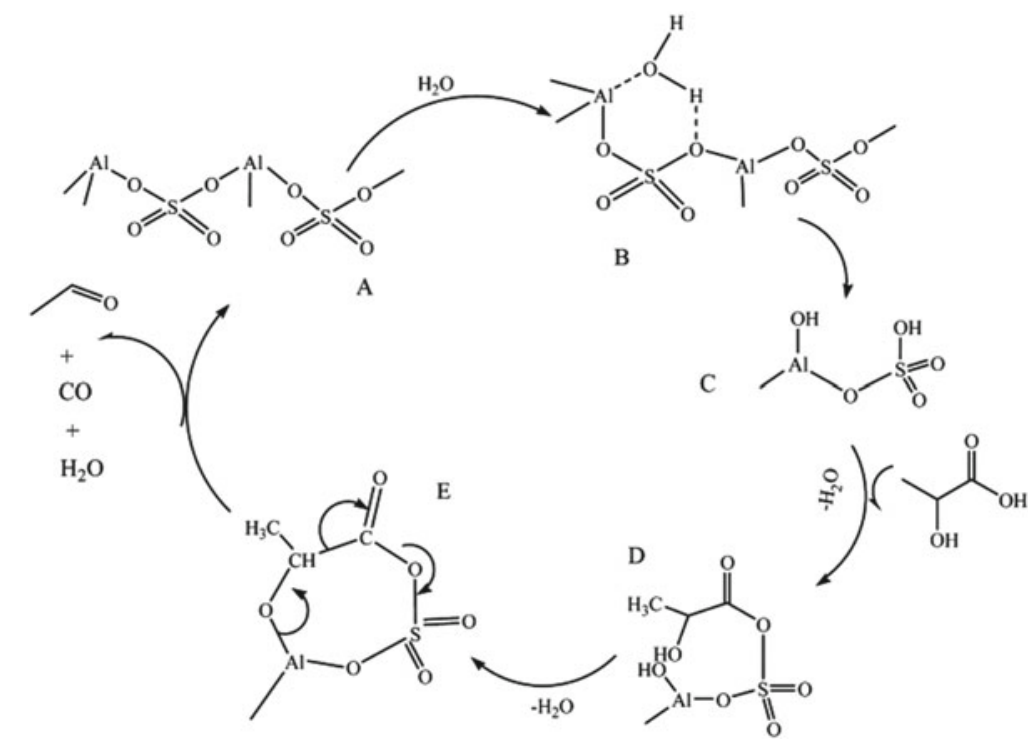

Fig. 3.12 Decarbonylation mechanism over aluminum sulfate proposed by Zhai et al. (Reprinted with permission from Ref. [51]. Copyright 2014 American Chemical Society)

The decarbonylation mechanism proposed to occur over aluminum sulfates [51] is shown in Fig. 3.12. The first step is the reaction of aluminum sulfate with water in order to hydroxylate the surface and to form the active species. Then, in the same way as Ghantani et al. [27], dissociative adsorption of lactic acid leads to formation of ester sulfate which then decomposes to acetaldehyde similarly to the ester phosphate.

Finally, Yan et al. [82] proposed an alternative mechanism for LA dehydration over hydroxyapatites (Fig. 3.13). Here, LA activation would take place on acidbase pairs corresponding to basic surface oxygen $(\mathrm{P}=\mathrm{O})$ and $\mathrm{Ca}^{2+}$ cations and leading to formation of $\mathrm{P}-\mathrm{OH}$ species and calcium lactates. In agreement with Gunter et al. [94, 95, 105-107, 113], formation of such lactate is believed to be the key parameter for LA dehydration by stabilizing the carbonyl group preventing decarbony(xy)lation.

To summarize, all these mechanisms involved different acid-base interactions between the active sites of the catalysts and functional groups of LA. As a general rule, the main by-product (ACE) was formed when high acidic sites were present on the catalysts while the selectivity to AA increased in the presence of mild basic or acidic sites. Further evidence to prove the real mechanism is still needed, especially with respect to the characterizations of the active sites under the actual reaction conditions. 


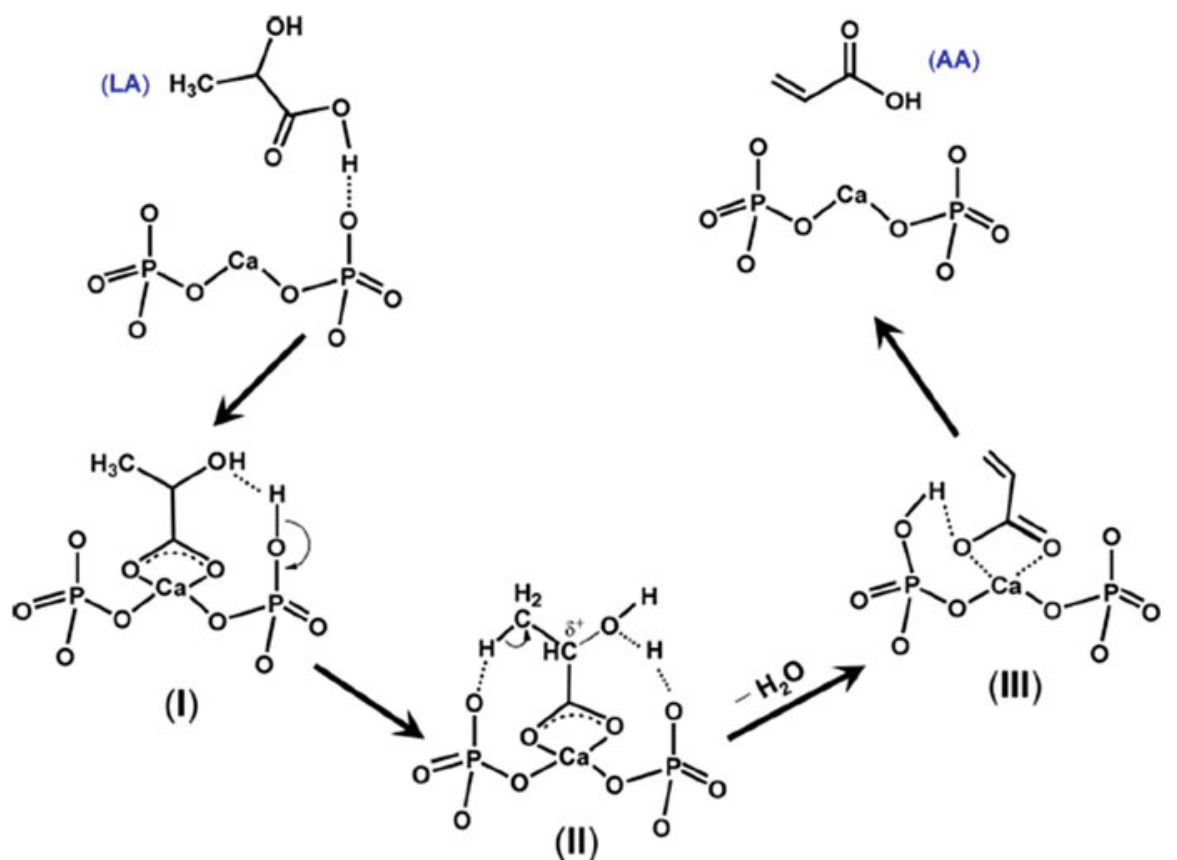

Fig. 3.13 Dehydration mechanism over hydroxyapatites proposed by Yan et al. (Reprinted with permission from Ref. [82]. Copyright 2014 American Chemical Society)

\subsection{Conclusion}

Significant recent improvements allow an efficient chemical synthesis of lactic acid either from glycerol or from diverse saccharides. High yields were achieved even under mild conditions, i.e., the approach is competitive with the biocatalytic one if racemic lactic acid is needed. However, few data focuses on the long-term stability of the catalysts engaged in the reaction as well as their behavior when lower purity starting materials are used. Yet, the catalyst performances are of significant importance mainly considering the cost of the process.

Lactic acid or alkyl lactate can be used to produce acrylic acid by dehydration. Even though high yields were reported in literature, discrepancies that could arise both from the analytical method and the reactant vaporization process appear. Furthermore, a key parameter to reach high yield is suitably balanced acid-base properties. High acidity leads to ACE formation, which is the most competitive route, whereas AA formation is favored by acid-base pairs in which acidic and basic sites are weak and/or moderated. Their maximization at the surface of catalysts would allow the design of more efficient catalysts and processes. 
Acknowledgments This work was founded by the French agency, Agence Nationale de la Recherche, Program Chimie Durable - Industries - Innovation (CD2I), project GALAC (reference ANR-2010-CD2I-011-01).

\section{References}

1. Johnson DT, Taconi KA (2007) The glycerin glut: options for the value-added conversion of crude glycerol resulting from biodiesel production. Environ Prog 26(4):336-348

2. Bozell JJ, Petersen GR (2010) Technology development for the production of biobased products from biorefinery carbohydrates-the US Department of Energy's "Top 10" revisited. Green Chem 12(4):539-554

3. Besson M, Gallezot P, Pinel C (2014) Conversion of biomass into chemicals over metal catalysts. Chem Rev 114(3):1827-1870

4. Fan Y, Zhou C, Zhu X (2009) Selective catalysis of lactic acid to produce commodity chemicals. Catal Rev 51(3):293-324

5. Mäki-Arvela P, Simakova IL, Salmi T, Murzin DY (2013) Production of lactic acid/lactates from biomass and their catalytic transformations to commodities. Chem Rev 114(3):1909-1971

6. Dusselier M, Van Wouwe P, Dewaele A, Makshina E, Sels BF (2013) Lactic acid as a platform chemical in the biobased economy: the role of chemocatalysis. Energy Environ Sci 6(5):1415-1442

7. Juodeikiene G, Vidmantiene D, Basinskiene L, Cernauskas D, Bartkiene E, Cizeikiene D (2015) Green metrics for sustainability of biobased lactic acid from starchy biomass vs chemical synthesis. Catal Today 239(1):11-16

8. Walsh P, Venus J (2013) D-lactic acid production. WO 2013164425

9. Chen X-Z, Tian K-M, Niu D-D, Shen W, Algasan G, Singh S, Wang Z-X (2014) Efficient bioconversion of crude glycerol from biodiesel to optically pure d-lactate by metabolically engineered Escherichia coli. Green Chem 16(1):342-350

10. Hayashi T, Mise T, Kumada M (1976) A chiral (hydroxyalkylferrocenyl)phosphine ligand. Highly stereoselective catalytic asymmetric hydrogenation of prochiral carbonyl compounds. Tetrahedron Lett 17(48):4351-4354

11. Ojima I, Kogure T, Nagai Y (1974) Asymmetric reduction of $\alpha$-keto esters via hydrosilylation catalyzed by a rhodium(I) complex with chiral phosphin ligands. Tetrahedron Lett 15(22):1889-1892

12. Dickins RS, Gaillard S, Hughes SP, Badari A (2005) Asymmetric catalysis by chiral lanthanide complexes in water. Chirality 17(7):357-363

13. Blaser HU, Jalett HP (1993) Enantioselective hydrogenation of $\alpha$-ketoacids using platinum catalysts modified with cinchona alkaloids. Stud Surf Sci Catal 78:139-146

14. Deng W, Zhang Q, Wang Y (2015) Catalytic transformations of cellulose and its derived carbohydrates into 5-hydroxymethylfurfural, levulinic acid, and lactic acid. Sci Chin Chem 58(1):29-46

15. Deng W, Zhang Q, Wang Y (2014) Catalytic transformations of cellulose and cellulosederived carbohydrates into organic acids. Catal Today 234(1):31-41

16. Wang Y, Deng W, Wang B, Zhang Q, Wan X, Tang Z, Wang Y, Zhu C, Cao Z, Wang G, Wan $\mathrm{H}$ (2013) Chemical synthesis of lactic acid from cellulose catalysed by lead(II) ions in water. Nat Commun 4:2141

17. Chambon F, Rataboul F, Pinel C, Cabiac A, Guillon E, Essayem N (2011) Cellulose hydrothermal conversion promoted by heterogeneous Brønsted and Lewis acids: Remarkable efficiency of solid Lewis acids to produce lactic acid. Appl Catal B 105(1-2):171-181 
18. Sun J, Liu H (2014) Selective hydrogenolysis of biomass-derived xylitol to ethylene glycol and propylene glycol on $\mathrm{Ni} / \mathrm{C}$ and basic oxide-promoted $\mathrm{Ni} / \mathrm{C}$ catalysts. Catal Today 234(1):75-82

19. Sun J, Liu H (2011) Selective hydrogenolysis of biomass-derived xylitol to ethylene glycol and propylene glycol on supported Ru catalysts. Green Chem 13(1):135-142

20. Zhang J, Lu F, Yu W, Chen J, Chen S, Gao J, Xu J (2014) Selective hydrogenative cleavage of $\mathrm{C}-\mathrm{C}$ bonds in sorbitol using $\mathrm{Ni}-\mathrm{Re} / \mathrm{C}$ catalyst under nitrogen atmosphere. Catal Today 234(1):107-112

21. Huo Z, Fang Y, Ren D, Zhang S, Yao G, Zeng X, Jin F (2014) Selective conversion of glucose into lactic acid with transition metal ions in diluted aqueous $\mathrm{NaOH}$ solution. ACS Sustain Chem Eng 2(12):2765-2771

22. Tang Z, Deng W, Wang Y, Zhu E, Wan X, Zhang Q, Wang Y (2014) Transformation of cellulose and its derived carbohydrates into formic and lactic acids catalyzed by vanadyl cations. ChemSusChem 7(6):1557-1567

23. Takagaki A, Jung JC, Hayashi S (2014) Solid Lewis acidity of boehmite [gamma]-AlO(OH) and its catalytic activity for transformation of sugars in water. RSC Adv 4(82):43785-43791

24. Lux S, Siebenhofer M (2013) Synthesis of lactic acid from dihydroxyacetone: use of alkalineearth metal hydroxides. Catal Sci Technol 3(5):1380-1385

25. Xu J, Zhang H, Zhao Y, Yu B, Chen S, Li Y, Hao L, Liu Z (2013) Selective oxidation of glycerol to lactic acid under acidic conditions using $\mathrm{AuPd} / \mathrm{TiO}_{2}$ catalyst. Green Chem 15(6): $1520-1525$

26. Katryniok B, Kimura H, Skrzynska E, Girardon J-S, Fongarland P, Capron M, Ducoulombier R, Mimura N, Paul S, Dumeignil F (2011) Selective catalytic oxidation of glycerol: perspectives for high value chemicals. Green Chem 13(8):1960-1979

27. Liu S-S, Sun K-Q, Xu B-Q (2014) Specific selectivity of Au-catalyzed oxidation of glycerol and other C3-polyols in water without the presence of a base. ACS Catal 4(7):2226-2230

28. Rodrigues EG, Carabineiro SAC, Delgado JJ, Chen X, Pereira MFR, Órfão JJM (2012) Gold supported on carbon nanotubes for the selective oxidation of glycerol. J Catal 285(1):83-91

29. Hirasawa S, Nakagawa Y, Tomishige K (2012) Selective oxidation of glycerol to dihydroxyacetone over a Pd-Ag catalyst. Catal Sci Technol 2(6):1150-1152

30. Nie R, Liang D, Shen L, Gao J, Chen P, Hou Z (2012) Selective oxidation of glycerol with oxygen in base-free solution over MWCNTs supported PtSb alloy nanoparticles. Appl Catal B 127(1):212-220

31. Hirasawa S, Watanabe H, Kizuka T, Nakagawa Y, Tomishige K (2013) Performance, structure and mechanism of $\mathrm{Pd}-\mathrm{Ag}$ alloy catalyst for selective oxidation of glycerol to dihydroxyacetone. J Catal 300(1):205-216

32. Morales M, Dapsens PY, Giovinazzo I, Witte J, Mondelli C, Papadokonstantakis S, Hungerbuhler K, Perez-Ramirez J (2015) Environmental and economic assessment of lactic acid production from glycerol using cascade bio- and chemocatalysis. Energy Environ Sci 8(2):558-567

33. Dapsens PY, Mondelli C, Pérez-Ramírez J (2013) Highly selective lewis acid sites in desilicated MFI zeolites for dihydroxyacetone isomerization to lactic acid. ChemSusChem 6(5):831-839

34. Cho HJ, Chang C-C, Fan W (2014) Base free, one-pot synthesis of lactic acid from glycerol using a bifunctional Pt/Sn-MFI catalyst. Green Chem 16(7):3428-3433

35. Purushothaman RKP, van Haveren J, Mayoral A, Melián-Cabrera I, Heeres HJ (2014) Exploratory catalyst screening studies on the base free conversion of glycerol to lactic acid and glyceric acid in water using bimetallic $\mathrm{Au}-\mathrm{Pt}$ nanoparticles on acidic zeolites. Top Catal 57(17-20): 1445-1453

36. Shen Y, Zhang S, Li H, Ren Y, Liu H (2010) Efficient synthesis of lactic acid by aerobic oxidation of glycerol on $\mathrm{Au}-\mathrm{Pt} / \mathrm{TiO}_{2}$ catalysts. Chem Eur J 16(25):7368-7371 
37. Lakshmanan P, Upare PP, Le N-T, Hwang YK, Hwang DW, Lee UH, Kim HR, Chang J-S (2013) Facile synthesis of $\mathrm{CeO}_{2}$-supported gold nanoparticle catalysts for selective oxidation of glycerol into lactic acid. Appl Catal A 468(1):260-268

38. Purushothaman RKP, van Haveren J, van Es DS, Melián-Cabrera I, Meeldijk JD, Heeres HJ (2014) An efficient one pot conversion of glycerol to lactic acid using bimetallic goldplatinum catalysts on a nanocrystalline $\mathrm{CeO}_{2}$ support. Appl Catal B 147(1):92-100

39. Li Y, Chen S, Xu J, Zhang H, Zhao Y, Wang Y, Liu Z (2014) Ni promoted Pt and Pd catalysts for glycerol oxidation to lactic acid. CLEAN - Soil, Air, Water 42(8):1140-1144

40. Ftouni J, Villandier N, Auneau F, Besson M, Djakovitch L, Pinel C. From glycerol to lactic acid under inert conditions in the presence of platinum-based catalysts: the influence of support. Catal Today. http://dx.doi.org/10.1016/j.cattod.2014.09.034

41. Sharninghausen LS, Campos J, Manas MG, Crabtree RH (2014) Efficient selective and atom economic catalytic conversion of glycerol to lactic acid. Nat Commun 5:5084

42. Auneau F, Noël S, Aubert G, Besson M, Djakovitch L, Pinel C (2011) On the role of the atmosphere in the catalytic glycerol transformation over iridium-based catalysts. Catal Commun 16(1):144-149

43. Maris EP, Ketchie WC, Murayama M, Davis RJ (2007) Glycerol hydrogenolysis on carbonsupported PtRu and AuRu bimetallic catalysts. J Catal 251(2):281-294

44. Auneau F, Michel C, Delbecq F, Pinel C, Sautet P (2011) Unravelling the mechanism of glycerol hydrogenolysis over rhodium catalyst through combined experimental-theoretical investigations. Chem Eur J 17(50):14288-14299

45. Kishida H, Jin F, Zhou Z, Moriya T, Enomoto H (2005) Conversion of glycerin into lactic acid by alkaline hydrothermal reaction. Chem Lett 34(11):1560-1561

46. Chen L, Ren S, Ye XP (2014) Lactic acid production from glycerol using $\mathrm{CaO}$ as solid base catalyst. Fuel Process Technol 120(1):40-47

47. Jamshidian M, Tehrany EA, Imran M, Jacquot M, Desobry S (2010) Poly-lactic acid: production, applications, nanocomposites, and release studies. Compr Rev Food Sci Food Safety 9(5):552-571

48. Prat D, Pardigon O, Flemming H-W, Letestu S, Ducandas V, Isnard P, Guntrum E, Senac T, Ruisseau S, Cruciani P, Hosek P (2013) Sanofi's solvent selection guide: a step toward more sustainable processes. Org Process Res Dev 17(12):1517-1525

49. Katryniok B, Paul S, Dumeignil F (2010) Highly efficient catalyst for the decarbonylation of lactic acid to acetaldehyde. Green Chem 12(11):1910-1913

50. Stirling A, Nair NN, Lledos A, Ujaque G (2014) Challenges in modelling homogeneous catalysis: new answers from ab initio molecular dynamics to the controversy over the Wacker process. Chem Soc Rev 43(14):4940-4952

51. Zhai Z, Li X, Tang C, Peng J, Jiang N, Bai W, Gao H, Liao Y (2014) Decarbonylation of lactic acid to acetaldehyde over aluminum sulfate catalyst. Ind Eng Chem Res 53(25): 10318-10327

52. China leads the world acrylic acid market in terms of both production \& consumption. http:// mcgroup.co.uk/news/20140508/china-leads-acrylic-acid-market-terms-productionconsumption.html

53. Ohara T, Sato T, Shimizu N, Prescher G, Schwind H, Weiberg O, Marten K, Greim H (2000) Acrylic acid and derivatives. In: Ullmann's encyclopedia of industrial chemistry. Wiley-VCH Verlag GmbH \& Co. KGaA, Weinheim

54. Acrylic acid and esters. https://www.ihs.com/products/acrylic-acid-acrylate-esters-chemicaleconomics-handbook.html

55. Tullo AH (2013) Hunting for biobased acrylic acid. Chem Eng News 91(46):18-19

56. http://www.icis.com/blogs/chemicals-and-the-economy/2010/03/ european-propylene-and-butadiene-prices-rise-above-ethylene/

57. Warnecke-Lipscomb TEL, Mike D, Gill Ryan T (2010) Methods, systems and compositions for increased microorganism tolerance to and production of 3-hydroxypropionic acid (3-HP). WO 2010011874 
58. Jung WS, Kang JH, Chu HS, Choi IS, Cho KM (2014) Elevated production of 3-hydroxypropionic acid by metabolic engineering of the glycerol metabolism in Escherichia coli. Metab Eng 23:116-122

59. Kumar V, Ashok S, Park S (2013) Recent advances in biological production of 3-hydroxypropionic acid. Biotechnol Adv 31(6):945-961

60. Tengler R, Decoster D, Hoyt S, Roach S (2013) Purification of 3-hydroxypropionic acid from crude cell broth and dehydration to acrylic acid. WO 2013192453

61. Adom F, Dunn JB, Han J, Sather N (2014) Life-cycle fossil energy consumption and greenhouse gas emissions of bioderived chemicals and their conventional counterparts. Environ Sci Technol 48(24):14624-14631

62. Katryniok B, Paul S, Dumeignil F (2013) Recent developments in the field of catalytic dehydration of glycerol to acrolein. ACS Catal 3(8):1819-1834

63. Lauriol-Garbey P, Loridant S, Bellière-Baca V, Rey P, Millet J-MM (2011) Gas phase dehydration of glycerol to acrolein over $\mathrm{WO}_{3} / \mathrm{ZrO}_{2}$ catalysts: Improvement of selectivity and stability by doping with $\mathrm{SiO}_{2}$. Catal Commun 16(1):170-174

64. Znaiguia R, Brandhorst L, Christin N, Bellière Baca V, Rey P, Millet J-MM, Loridant S (2014) Toward longer life catalysts for dehydration of glycerol to acrolein. Microporous Mesoporous Mater 196(1):97-103

65. Chieregato A, Soriano MD, Basile F, Liosi G, Zamora S, Concepción P, Cavani F, López Nieto JM (2014) One-pot glycerol oxidehydration to acrylic acid on multifunctional catalysts: Focus on the influence of the reaction parameters in respect to the catalytic performance. Appl Catal B 150-151(1):37-46

66. Chieregato A, Soriano MD, García-González E, Puglia G, Basile F, Concepción P, Bandinelli C, López Nieto JM, Cavani F (2015) Multielement crystalline and pseudocrystalline oxides as efficient catalysts for the direct transformation of glycerol into acrylic acid. ChemSusChem 8(2):398-406

67. Lee W-J, Choe Y-J, Nam H, Kong M-J (2014) Method for producing acrylic acid from glycerol. WO 2014209065

68. Yi J, Liu S, Abu-Omar MM (2012) Rhenium-catalyzed transfer hydrogenation and deoxygenation of biomass-derived polyols to small and useful organics. ChemSusChem 5(8):1401-1404

69. Global Industry Analysis, Inc. Lactic Acid Global Strategic Business Report (2012) http:// www.researchandmarkets.com/reports/354880/lactic_acid_global_strategic_business_report

70. Aida TM, Ikarashi A, Saito Y, Watanabe M, Smith RL Jr, Arai K (2009) Dehydration of lactic acid to acrylic acid in high temperature water at high pressures. J Supercrit Fluids 50(3):257-264

71. Lira CT, McCrackin PJ (1993) Conversion of lactic acid to acrylic acid in near-critical water. Ind Eng Chem Res 32(11):2608-2613

72. Mok WSL, Antal MJ, Jones M (1989) Formation of acrylic acid from lactic acid in supercritical water. J Org Chem 54(19):4596-4602

73. Danner H, Ürmös M, Gartner M, Braun R (1998) Biotechnological production of acrylic acid from biomass. Appl Biochem Biotechnol 70-72(1):887-894

74. Odell B, Earlam G, Cole-Hamilton DJ (1985) Hydrothermal reactions of lactic acid catalysed by group: VIII Metal complexes. J Organomet Chem 290(2):241-248

75. Paparizos C, Dolhyj SR, Shaw WG (1988) Catalytic conversion of lactic acid and ammonium lactate to acrylic acid. US Patent 4786756

76. Sawicki RA (1988) Catalyst for dehydration of lactic acid to acrylic acid. US19870045633

77. Dongare MK, Umbarkar SB, Lomate S (2014) An improved process for catalytic dehydration of lactic acid to acrylic acid. US 2014/0155653

78. Villalobos JL, Ioannis CD (2013) Catalytic conversion of lactic acid to acrylic acid. WO2013US36070

79. Zhang JF, Zhao YL, Feng XZ, Pan M, Zhao J, Ji WJ, Au CT (2014) $\mathrm{Na}_{2} \mathrm{HPO}_{4}$-modified $\mathrm{NaY}$ nanocrystallites: efficient catalyst for acrylic acid production through lactic acid dehydration. Catal Sci Technol 4(5):1376-1385 
80. Yan B, Tao L-Z, Liang Y, Xu B-Q (2014) Sustainable production of acrylic acid: Alkali-ion exchanged beta zeolite for gas-phase dehydration of lactic acid. ChemSusChem 7(6): $1568-1578$

81. Peng J, Li X, Tang C, Bai W (2014) Barium sulphate catalyzed dehydration of lactic acid to acrylic acid. Green Chem 16(1):108-111

82. Yan B, Tao L-Z, Liang Y, Xu B-Q (2014) Sustainable production of acrylic acid: Catalytic performance of hydroxyapatites for gas-phase dehydration of lactic acid. ACS Catal 4(6):1931-1943

83. Ghantani VC, Dongare MK, Umbarkar SB (2014) Nonstoichiometric calcium pyrophosphate: a highly efficient and selective catalyst for dehydration of lactic acid to acrylic acid. RSC Adv 4(63):33319-33326

84. Sun P, Yu D, Fu K, Gu M, Wang Y, Huang H, Ying H (2009) Potassium modified NaY: a selective and durable catalyst for dehydration of lactic acid to acrylic acid. Catal Commun 10(9): 1345-1349

85. Sun P, Yu D, Tang Z, Li H, Huang H (2010) NaY zeolites catalyze dehydration of lactic acid to acrylic acid: studies on the effects of anions in potassium salts. Ind Eng Chem Res 49(19):9082-9087

86. Wang H, Yu D, Sun P, Yan J, Wang Y, Huang H (2008) Rare earth metal modified NaY: structure and catalytic performance for lactic acid dehydration to acrylic acid. Catal Commun 9(9):1799-1803

87. Yan J (2011) Catalytic dehydration of lactic acid to acrylic acid over NaY zeolites modified with metallic ions. Shiyou Huagong/Petrochemical Technol 40(5):476

88. Yan J, Yu D, Li H, Sun P, Huang H (2010) NaY zeolites modified by $\mathrm{La}^{3+}$ and $\mathrm{Ba}^{2+}$ : the effect of synthesis details on surface structure and catalytic performance for lactic acid to acrylic acid. J Rare Earths 28(5):803-806

89. Yan J, Yu D, Sun P, Huang H (2011) Alkaline earth metal modified NaY for lactic acid dehydration to acrylic acid: Effect of basic sites on the catalytic performance. Chin J Catal 32(3-4):405-411

90. Zhang J, Zhao Y, Pan M, Feng X, Ji W, Au C-T (2010) Efficient acrylic acid production through bio lactic acid dehydration over NaY zeolite modified by alkali phosphates. ACS Catal 1(1):32-41

91. Zhang J, Lin J, Cen P (2008) Catalytic dehydration of lactic acid to acrylic acid over sulfate catalysts. Can J Chem Eng 86(6):1047-1053

92. Zhang J, Feng X, Zhao Y, Ji W, Au C-T (2014) Sodium nitrate modified SBA-15 and fumed silica for efficient production of acrylic acid and 2,3-pentanedione from lactic acid. J Ind Eng Chem 20(1):1353-1358

93. Ghantani VC, Lomate ST, Dongare MK, Umbarkar SB (2013) Catalytic dehydration of lactic acid to acrylic acid using calcium hydroxyapatite catalysts. Green Chem 15(5):1211-1217

94. Gunter GC, Craciun R, Tam MS, Jackson JE, Miller DJ (1996) FTIR and 31P-NMR spectroscopic analyses of surface species in phosphate-catalyzed lactic acid conversion. J Catal 164(1):207-219

95. Gunter GC, Miller DJ, Jackson JE (1994) Formation of 2,3-pentanedione from lactic acid over supported phosphate catalysts. J Catal 148(1):252-260

96. Hong JH, Lee J-M, Kim H, Hwang YK, Chang J-S, Halligudi SB, Han Y-H (2011) Efficient and selective conversion of methyl lactate to acrylic acid using $\mathrm{Ca}_{3}\left(\mathrm{PO}_{4}\right) 2-\mathrm{Ca}_{2}\left(\mathrm{P}_{2} \mathrm{O}_{7}\right)$ composite catalysts. Appl Catal A 396(1-2):194-200

97. Lee J-M, Hwang D-W, Hwang YK, Halligudi SB, Chang J-S, Han Y-H (2010) Efficient dehydration of methyl lactate to acrylic acid using $\mathrm{Ca}_{3}\left(\mathrm{PO}_{4}\right) 2-\mathrm{SiO}_{2}$ catalyst. Catal Commun 11(15):1176-1180

98. Matsuura Y, Onda A, Ogo S, Yanagisawa K (2014) Acrylic acid synthesis from lactic acid over hydroxyapatite catalysts with various cations and anions. Catal Today 226(1):192-197

99. Matsuura Y, Onda A, Yanagisawa K (2014) Selective conversion of lactic acid into acrylic acid over hydroxyapatite catalysts. Catal Commun 48(1):5-10 
100. Tang C, Peng J, Li X, Zhai Z, Jiang N, Bai W, Gao H, Liao Y (2014) Strontium pyrophosphate modified by phosphoric acid for the dehydration of lactic acid to acrylic acid. RSC Adv 4(55):28875-28882

101. Zhang Z, Qu Y, Wang S, Wang J (2009) Catalytic performance and characterization of silica supported sodium phosphates for the dehydration of methyl lactate to methyl acrylate and acrylic acid. Ind Eng Chem Res 48(20):9083-9089

102. Zhang Z, Qu Y, Wang S, Wang J (2010) Theoretical study on the mechanisms of the conversion of methyl lactate over sodium polyphosphate catalyst. J Mol Catal A Chem 323(1-2):91-100

103. Blanco E, Delichere P, Millet JMM, Loridant S (2014) Gas phase dehydration of lactic acid to acrylic acid over alkaline-earth phosphates catalysts. Catal Today 226(1):185-191

104. Näfe G, Traa Y, Hirth T, Klemm E (2014) True catalytic behavior of lactic acid dehydration on zeolite $\mathrm{Na}-\mathrm{Y}$ in the gas phase measured by means of a novel apparatus design. Catal Lett 144(7):1144-1150

105. Wadley DC, Tam MS, Kokitkar PB, Jackson JE, Miller DJ (1997) Lactic acid conversion to 2,3-pentanedione and acrylic acid over silica-supported sodium nitrate: reaction optimization and identification of sodium lactate as the active catalyst. J Catal 165(2):162-171

106. Tam MS, Craciun R, Miller DJ, Jackson JE (1998) Reaction and kinetic studies of lactic acid conversion over alkali-metal salts. Ind Eng Chem Res 37(6):2360-2366

107. Tam MS, Gunter GC, Craciun R, Miller DJ, Jackson JE (1997) Reaction and spectroscopic studies of sodium salt catalysts for lactic acid conversion. Ind Eng Chem Res 36(9):3505-3512

108. Deka RC, Hirao K (2002) Lewis acidity and basicity of cation-exchanged zeolites: QM/MM and density functional studies. J Mol Catal A Chem 181(1-2):275-282

109. Tam MS, Jackson JE, Miller DJ (1999) Effects of ammonium lactate on 2,3-pentanedione formation from lactic acid. Ind Eng Chem Res 38(10):3873-3877

110. Diallo-Garcia S, Osman MB, Krafft J-M, Casale S, Thomas C, Kubo J, Costentin G (2014) Identification of Surface Basic Sites and Acid-base Pairs of Hydroxyapatite. J Phys Chem C 118(24):12744-12757

111. Hammaecher C, Paul J-F (2013) Density functional theory study of lactic acid adsorption and dehydration reaction on monoclinic $011,-101$ and -111 zirconia surfaces. J Catal 300(1):174-182

112. Pandey LB, Aikens CM (2013) Theoretical investigation of surface reactions of lactic acid on $\mathrm{MgO}$ clusters. J Phys Chem A 117(4):765-770

113. Gunter GC, Langford RH, Jackson JE, Miller DJ (1995) Catalysts and supports for conversion of lactic acid to acrylic acid and 2,3-pentanedione. Ind Eng Chem Res 34(3):974-980

114. Burns R, Jones DT, Ritchie PD (1935) Studies in pyrolysis. Part I. The pyrolysis of derivatives of $\alpha$-acetoxypropionic acid, and related substances. J Chem Soc 88(1):400-406

115. Fisher CH, Ratchford WP, Smith LT (1944) Methyl acrylate production by pyrolysis of methyl acetoxypropionate. Ind Eng Chem 36(3):229-234 